ARTICLE

https://doi.org/10.1057/s41599-019-0320-z

\title{
Speaking of trauma: the race talk, the gun violence talk, and the racialization of gun trauma
}

Madison Armstrong ${ }^{1} \&$ Jennifer Carlson ${ }^{1 \star}$

\begin{abstract}
This paper considers the intersection of race and gun violence through the lens of trauma. We focus on two high-profile cases of gun violence: the state-deemed justifiable homicide of Trayvon Martin in Sanford, Florida, on February 26, 2012 and the active shooting that took place at Marjory Stoneman Douglas High School in Parkland, Florida, on February 14, 2018. These cases illustrate not just how people in the US experience gun violence in racially divergent ways (as existing literature suggests) but also how people-particularly parents-manage the anticipation of gun violence and its trauma. To this end, we develop the concept of "anticipatory trauma" and illustrate it by analyzing a set of social practices that have emerged surrounding gun violence: parents' conversations with their children aimed at explaining and addressing their children's unique risk of gun violence. Building on existing literature on "the Talk" among African American parents, we analyze a racial bifurcation in how parents talk about gun violence. Specifically, we detail "the Race Talk" (in relation to the Trayvon Martin case) and "the Gun Violence Talk" (in relation to the Parkland case), which differentially construct children's vulnerability, the social phenomena that render them vulnerable, and the appropriate solutions for addressing that vulnerability. Without understanding anticipatory trauma as a racialized phenomenon, we risk leveling the gun violence debate-and creating gun policy that is neither politically meaningful nor practically effective for addressing the broad but complex issue of gun violence.
\end{abstract}

${ }^{1}$ School of Sociology, University of Arizona, Social Sciences Building, Tucson, AZ 85721, USA. *email: jennifercarlson@email.arizona.edu 


\section{Introduction}

n February 26, 2012, 17-year-old Trayvon Martin wanted to get an Arizona Iced Tea for himself and Skittles for his soon-to-be younger step-brother. It was dark and rainy, but he made the trek through the Sanford, Florida, gated community known as The Retreat on Twin Lakes. As he made his way back from 7-11 after purchasing the items, he dialed his friend Rachel Jeantel, who was the last person to talk to Martin before he died. Martin, trying to avoid the rain, noticed someone following him: George Zimmerman, self-appointed neighborhood watch captain. From Zimmerman's perspective, Martin was an unrecognized black male in a hoodie-suspect, especially amid a recent spate of break-ins in the neighborhood. Despite being advised by police to back off, Zimmerman, complaining to police that "these assholes, they always get away," decided to follow Martin. Jeantel advised Martin to run; Martin intimated that he was sick of running. Jeantel could hear the sounds of a confrontation, but the phone cut out before Zimmerman shot a bullet into Martin's chest, killing him. Police questioned Zimmerman, but ultimately released him; given the state's Stand Your Ground law, Floridians' generally sympathetic stance on the defensive use of force, and the fact that Zimmerman was the only witness left to narrate what happened, police found themselves reticent to arrest-so they let him go. Within about two weeks, the case sparked protests in Florida and across the nation. Only after tremendous public pressure did a special prosecutor notorious for putting African Americans behind bars decide to charge Zimmerman; nearly a year and a half later, on July 13, 2013, Zimmerman was found "not guilty" of all charges by an all-female jury.

On the afternoon of February 14, 2018, shortly before school let out for the day, expelled student Nikolas Cruz entered Building 12 of Marjory Stoneman Douglas High School in Parkland, Florida, carrying a semiautomatic AR-15 rifle. Cruz began firing the gun; its smoke set off the fire alarm, sending confused students and faculty into the hallways. Cruz fired into multiple classrooms as students and staff, realizing what was happening, desperately tried to take shelter or escape the campus. Within the span of $6 \mathrm{~min}$, Cruz killed seventeen people and injured another seventeen in and around the high school. He abandoned his weapon and escaped the building by blending in with students fleeing the gunfire. Cruz then visited a nearby Walmart, purchased a drink from a Subway, and briefly entered a McDonalds before being apprehended by police while walking through a neighborhood over an hour after the shootings. Cruz confessed to the shootings and was ultimately charged with seventeen counts of premeditated murder in the first degree and seventeen counts of attempted murder in the first degree; as of the writing of this article, the case has yet to go to trial. Although scholarship shows that the majority of mass murders are carried out by young, middle-class white men (Fox and Levin, 1998; Madfis, 2014), the attack came as a shock to the affluent, predominately white Parkland community, destabilizing the community's sense of safety. Within one day of the Parkland shootings, members of the community, including those who were not affiliated with the high school, began protesting in favor of gun violence prevention.

In the US, nearly 40,000 people die of gunshot wounds annually; nearly 100,000 are wounded every year. These figures are overwhelming, but still they greatly underestimate who is impacted by gun violence, how, and with what consequences. Extrapolating from these figures suggests that hundreds of thousands of friends and family experience trauma as they cope with casualties due to firearms - and hundreds of thousands more experience trauma as they anticipate gun violence in their streets, at home, and in their schools. Parents of diverse backgrounds are proactively concerned with how to manage their children's safety amid the threat of gun violence. This may mean choosing housing on the basis of school and neighborhood safety, setting ground rules for kids' playdates and extracurricular activities, and even engaging in security consumption, such as buying bulletproof backpacks. It also means engaging in particular practices of talking to kids about gun violence. Indeed, news coverage in the aftermath of gun violence tragedies suggests that while school shootings and justifiable homicides have incited parents across racial and socioeconomic divides to talk to their kids about gun violence, these brands of gun violence have elicited fundamentally different strategies among parents as they aim to protect children physically and emotionally from the anticipated threat of gun violence.

This paper considers gun violence through the lens of trauma. To unravel the trauma that gun violence incites, we focus on two high-profile cases of gun violence with markedly different racial dynamics: the state-deemed justifiable homicide of Trayvon Martin on February 26, 2012 and the active shooting that occurred at Marjory Stoneman Douglas High School on February 14,2018 . These cases illustrate a number of broader points that scholars have made about trauma, namely, that (1) trauma is a long-term, dynamic process; (2) trauma is inflected by lines of difference and inequality, including race, gender, and class; and (3) trauma operates as a micro-level, meso-level, and macro-level phenomenon that extends far beyond the immediate victims of a traumatic event. We build on this literature to further detail the consequences of trauma-not just for understanding how people in the US experience gun violence in racially divergent ways but also how people-particularly parents-in the US manage the anticipation of gun violence. To this end, we develop the concept of "anticipatory trauma" and illustrate it by analyzing a set of social practices that have emerged surrounding gun violence: parents' conversations with their children aimed at explaining and addressing their children's unique risk of gun violence. We then turn to the coverage of the Trayvon Martin and Parkland cases to unpack how parents' gun violence talk is mobilized across different kinds of gun violence. Rather than an empirically exhaustive account, we take a theoretically motivated reading of mainstream news outlets' coverage of these parental talks in order to develop a set of claims regarding anticipatory trauma, gun violence, and race. Specifically, we analyzed op-ed pieces from national and local news sources that referenced either the Trayvon Martin case or the Parkland case directly and discussed speaking to children about either event or gun violence more generally. News sources examined included The Washington Post, The New York Times, The Atlantic, CNN, ABC News, NBC News, USA Today, Today, The Huffington Post, NPR, The Baltimore Sun, The South Florida Sun Sentinel, and My San Antonio. All articles were published between the date of the event which they referenced (the shooting of Martin on February 26, 2012 and the Parkland shootings on February 14, 2018) and March 2019. Op-ed topics were sorted into themes pertaining to perceptions of danger, precautions taken against violence, perception of authority, maintenance of emotions, and institutional support (or lack thereof). Often resembling "how to" guides for worried parents, these news articles can be understood as theoretically generative social texts that "bear witness" to social injury (Eyerman, 2019) and, as such, provide a window into cultural trauma surrounding gun violence.

We find that parents' talk about gun violence entrenches racial differences in not only understanding but also responding to gun violence as an everyday threat. In other words, we suggest that anticipatory trauma acts as a vehicle of racialization. In doing so, we build on existing literature on "the Talk" among African 
American parents (Dow, 2016; Gonzales, 2019), and we detail a racial bifurcation in the ways anticipatory trauma is engaged through two racially distinct practices of parental talk. Specifically, we detail the "the Race Talk" (in relation to the Trayvon Martin case) and "the Gun Violence Talk" (in relation to the Parkland case), which differentially construct children's vulnerability, the social phenomena that render them vulnerable, and the appropriate solutions for addressing that vulnerability. Both talks are implicitly racialized in that they both depend on racially divergent presumptions regarding social support, personal efficacy, and risk in society, but the explicitness of their racial politics is different: following the politics of colorblindness, the Race Talk explicitly frames gun violence as a problem of race, but in ways that tend to particularize gun violence associated with racially and socioeconomically marginalized people as a "problem of race." In contrast, the Gun Violence Talk generalizes the trauma associated with racially and socioeconomically privileged people as a "problem of gun violence."

Similarly motivated by children's vulnerability to gun violence, the racially divergent ways in which "the Talk" emerges in the aftermath of these high-profile gun tragedies illustrate how the anticipatory trauma of gun violence is lived as an everyday, racialized politics embedded in homes and families across the US, above and beyond direct experiences with gun violence. We conclude by inverting our original concern-how gun violence shapes trauma-to consider how trauma shapes gun violence, at least insofar as trauma can impact how we talk about, debate, and ultimately develop policies that impact gun violence. Anticipatory trauma is a mechanism by which certain acts of gun violence are defined as "really" about certain social problems (e.g., race or gun violence) and not others; it is a mechanism by which certain experiences of gun violence become hypervisible versus invisible; and finally, it is a mechanism by which polities are rallied and policies drafted. Thus, without understanding anticipatory trauma as a racialized phenomenon, we risk leveling the gun violence debate-and creating gun policy that is neither politically meaningful nor practically effective for addressing the broad but complex issue of gun violence.

\section{The traumatic terrain of US gun violence}

More Americans have died by guns since 1968 than have died in wars across US history. Gun violence costs an average of $\$ 700$ per year per American. From death counts to lost productivity, countless statistics and figures communicate the sheer enormity of gun violence in the US. Each, however, conceals a great deal of variation within gun violence. The majority of gun deaths are suicides, which are disproportionately white men; about 10,000 felonious gun homicides occur every year, and African American boys and men are disproportionately likely to be both perpetrators and victims of this form of gun violence. African American boys and men are also disproportionately likely to be killed in justifiable homicides: suggestive of the weapons bias, whereby objects associated with darker-skinned people are more likely to be quickly identified as guns than objects associated with lighterskinned people (Payne, 2006), white-on-black homicides are more likely to be ruled justifiable in states with Stand Your Ground policies (Roman, 2013). According to Washington Post and FBI Uniform Crime Report data, every year roughly 1300 people die in justifiable homicides by civilians and law enforcement (Tate et al., 2016). Finally, among active shootings that involve a shooter indiscriminately killing in a public and/or populated area, whites are more represented as both perpetrators (who are almost exclusively white boys and men) and victims, and, according to an analysis by The Guardian, active shootings occur, on average, 9 out of 10 days in the US (Morris, 2018).
Further, race shapes how trauma is experienced in the aftermath of gun violence for those who survive it. "Traumatic events" are often considered to be drastic and shocking departures from the norm of everyday life, including incidents such as witnessing a violent death, loss of a loved one (particularly through violent means), and single occurrence or prolonged abuse (Alexander, 2012; Herman, 2015; Morrison and Casper, 2012). As Eyerman (2019, p. 89) describes,

"trauma" here in its common meaning as the impact of shocking occurrences that profoundly affect an individual's life. Such "inner catastrophes" leave wounds and memory scars that cannot easily be erased and that influence later behavior in unexpected and unpredictable ways.

Sociologists, psychologists, and other scholars have parsed trauma as an individual, collective and cultural phenomenon. Individual trauma is described as psychological trauma stemming from some specific traumatic event that affects an individual either directly, as in cases of physical abuse, or indirectly, as in the aftermath of the loss of a loved one. Collective traumas are defined as those that affect many people who belong to the same cultural group or collectivity (Alexander, 2012; Eyerman, 2013; Herman, 2015; McGuffey, 2005); similar to individual trauma, collective trauma is born of a specific event and negatively impacts not only the psyche of the individual people within the collectivity, but also the bonds between its members (Erikson, 1976; Eyerman, 2013). Trauma may result in psychological conditions such as post-traumatic stress disorder or complex posttraumatic stress disorder, a prolonged recovery process, and/or the embodiment of physical symptoms or effects of the traumatic event. Homicide survivors are likely to experience psychological and physical effects (Hertz and Chery, 2005), and mothers are particularly likely to bear "multiple burdens" of being aggrieved by the loss of a loved one to homicide, stigmatized by virtue of their social proximity to a homicide victim, and expected, within their social networks, to ameliorate the trauma of other survivors (Bailey et al., 2013; Melendez et al., 2016). Scholarship shows that exposure to gun violence (even if not directly victimized) is disproportionately concentrated in poor communities of color, and it shapes mental health, long-term physical health, cognitive abilities, and even friendship structures (Chan Tack and Small, 2017; Sharkey, 2010; Sharkey et al., 2012). Further, individual and collective traumas may serve to reinforce one another and may also be connected with cultural trauma (Eyerman, 2019).

Cultural trauma is central for understanding the broad effects of gun violence in the US. Rather than emerging in the aftermath of a close brush with a traumatic event, cultural trauma describes the processes by which collective memories are narrated as trauma to mediate collective identity (Eyerman, 2019; see also Smelser, 2004): "to become a cultural trauma, an event or situation must not only be disorienting but must also get defined and narrated as trauma" (Onwuachi-Willig, 2016, p. 339, citing Eyerman, 2015). Drawing on broadly held ideas about identity, injury, belonging and blameworthiness, cultural trauma is distinct from collective trauma and individual trauma in at least three ways. First, cultural trauma is a discursive process that is channeled through social institutions shaped by race and gender, including existing social supports (particularly racial disparities in the resources and tools available to individuals and communities experiencing trauma); the responsiveness of the existing structures, such as the political and legal system, to grievances (political institutions, for example, tend to be more responsive to claims by privileged claims-makers); and the racial narratives of blameworthiness and criminality (especially in the case of trauma due to violent death) that shape the meaning-for survivors and beyond-of these traumatic deaths. Second, cultural trauma can 
disrupt temporality with respect to traumatic events. As Schmidt (2014) shows, cultural trauma may emerge not just in the aftermath of a particular event but also in anticipation of such an event, an anticipation that is likely to draw on stylized narratives of blameworthiness, victimhood, and injury shaped. Finally, as Onwuachi-Willig (2016) importantly argues, cultural trauma describes not just disturbing disruptions to the routine; cultural trauma also can emerge from routinized harm perpetrated against a subordinated group when it is recognized in the public arena and sanctioned or reinforced by government and legal forces. The perpetration of gun violence by police and private civilians against Black individuals in the United States is a key example of this; it is a routinized harm against a marginalized group of which the public at large is aware and which is frequently discussed by media outlets, but which is also tacitly or explicitly sanctioned by the government and legal forces (Onwuachi-Willig, 2016). Thus, cultural trauma provides key analytical insights for understanding how gun violence induces trauma in its aftermath and in its anticipation, and how this bi-directional relationship between trauma and gun violence is shaped by the racial disparities in how gun violence is experienced and understood.

\section{Racializing gun violence-related trauma}

To illustrate how race shapes trauma, we first consider the two cases-the killing of Trayvon Martin on February 26, 2012 and the Parkland Shooting on February 14, 2018-across three axes that shape trauma in the aftermath of gun violence: (1) social supports, (2) the responsiveness of the political and legal systems to the grievances of survivors, and (3) racial narratives of blameworthiness and criminality.

Social support. The survivors of the Trayvon Martin and Parkland tragedies navigated racially disparate contexts of social support. The Parkland tragedy was met with an immediate outpouring of public support and resources, including counseling and mental health services, memorials, and public commemoration. Within days, public events were held to provide space for families and friends to grieve and process the tragedy, and makeshift shrines were soon erected-and preserved for weeks-at Pine Trails Park nearby. Other memorials would take longer to erect; in early 2019, a "Project Grow Love" memorial garden was unveiled on the school's campus. Such resources should not suggest that the enduring trauma that survivors experienced was resolutely addressed; for instance, when two students who survived the attack died by suicide around the one-year anniversary of the killing, some criticized the memorial services, saying that students had been "expected to brush aside our grief and deep mental wounds." In response, Broward County officials met to discuss further supporting students and reminded the community of resources in the form of resiliency centers and crisis hotlines.

Even these generous resources proved inadequate to the tall task of resolving complex trauma. And so we must remember that most gun tragedies do not warrant such an outpouring. Before his parents-with the help of their lawyer, Benjamin Crumptransformed his death into a public cause, Trayvon Martin's homicide was largely invisible to the public at large, and his death did not warrant any specially organized resources in the form of mental health counseling or other social supports, not least because his death was deemed "justifiable". Martin was not just killed but also criminalized. The violent deaths of African American boys and men, as writers such as Jill Leovy and Alex Kotlowitz show, are more likely to pass unnoticed by the public and are largely perfunctorily engaged by legal authorities. As such, Martin's family was effectively left to navigate the legal and emotional aftermath of their son's death on their own.
The responsiveness of political and legal channels. Intersecting with disparities in social supports in the aftermath of gun violence, the survivors of the Trayvon Martin and Parkland tragedies also experienced divergences in the responsiveness of political and legal channels to their demands for justice and restitution. For Trayvon Martin's family, grief and justice were counterposed: Martin's father, Tracy Martin, recounts having to grapple with the immediate reality that “just hearing a father's cry isn't going to do it" when it comes to bringing justice; Sybrina Fulton, Martin's mother, initially struggled with the traumatic loss of her child by withdrawing. But Martin's parents had to make a choice, Crump insisted: "either you choose to grieve, or you choose to fight." And, Crump continued, "if you choose to grieve, it's over. Nothing happens to the killer of your child." If they chose to grieve, they failed their son and other victims of justifiable homicide. If they chose to fight, they necessarily made their own struggle to grieve more difficult, especially if they lost the fight. The strategy of turning to activism after a traumatic event has a significant history among Black mothers, particularly in the aftermath of the violent deaths of their children (Al'Uqdah and Adomako, 2018; Armour, 2002; Bailey et al., 2013; Price, 2017). Framing the case around issues of racial inequality, civil rights and anti-racist activists mobilized first for the arrest of Zimmerman, then for his conviction, and finally against his acquittal under the banner of \#BlackLivesMatter. Ultimately, however, these activists lost the battle for justice in the courts: Martin's killing was followed by the "not guilty" verdict, which acted as a double trauma. First, it was a reminder that Black bodies are not safe from physical harm, and second, a rejoinder that Black bodies are not worthy of legal redress.

Whereas Martin's family fought to raise political and legal questions about Martin's death, Parkland students were eagerly embraced as the next generation of gun violence activists, and the legal system quickly moved to arrest and charge the shooter. Schmidt (2014) explains that anticipatory trauma may be mobilized to promote collective action aimed at preempting perceived threat. Following the Parkland shootings, individuals (particularly white individuals) who had perhaps not considered the possibility of facing gun violence previously began to experience a level of anticipatory trauma that spurred them to action. Many of the students and parents who faced individual traumas in the aftermath of the Stoneman Douglas shootings turned to activism focused on gun violence prevention as a way of processing trauma and attempting to make meaning out of the event. Parents also engaged in activism on behalf of the children they lost. In contrast with Martin's family, the Parkland activists were given immense political capital. With the help of wellconnected, big-dollar funders like actor George Clooney, several students from the school became essential in organizing and promoting the March for Our Lives, a gun violence prevention march that was held in Washington, D.C. a month after the Parkland shootings, as well as a nationwide activism tour in the summer of 2018. As Dave Cullen (2019) documents in his book Parkland, these largely suburban, affluent, and mostly white students came face-to-face with racial disparities in the responsiveness of political channels; joining with activists of color involved in fighting urban gun violence in Chicago, Parkland activists openly and explicitly emphasized that all kids deserved to live in a world as they realized that their privileged racial and class status made their calls to end gun violence more politically salient than the claims of less privileged kids facing gun violence.

Narratives of blameworthiness and criminality. In both cases, trauma was shaped-both for survivors and for broader communities-by the racial narratives of blameworthiness and 
criminality that shaped how perpetrators and victims in the two cases were understood. As the Trayvon Martin killing become publicly defined as a tragedy of race rather than a tragedy of gun violence, activists questioned how Martin's racial status contributed to his being framed as the "real" aggressor and Zimmerman as the "real" victim. Zimmerman's acquittal made visible the deep racial divides surrounding these narratives of blameworthiness and criminality in the US: nearly half of whites (49\%) polled in a Pew (2013) survey said they were "satisfied" with the outcome, while the vast majority of African Americans (86\%) were "dissatisfied." For many whites, the case may have been merely another murder trial; for African Americans, it was a reckoning with the realities of being Black in America. Referencing the Emmett Till murder, protesters noted with anger that "Only in America must a Black boy stand trial for his own murder," while then-President Obama acknowledged the cruelty with which skin color criminalizes Black boys, saying "If I had a son, he'd look like Trayvon." As powerful as such statements were in calling attention to the lethal consequences of race in America and the racial terror that African Americans navigate as a condition of their everyday lives, these statements tended to reinforce the message that the case mattered first and foremost to Black Americans, rather than Americans more generally. In addition, the case served as a reminder of the particular precarity of being a Black boy in America-the language referring to sons and boys reflects the gendering of gun violence, especially gun-related justifiable homicides, which disproportionately impact Black boys and men (see Gonzalez, 2019).

In contrast, the Parkland shooting-like mass shootings more generally-was framed as an attack on "normal kids" doing "normal things" and, as such, an attack on white, middle-class American life. The victims in this case are distinctly degendered; unlike in the Trayvon Martin case, the rhetoric focuses on the gender-neutral "schoolchildren," seemingly made precarious only by their proximity to schools. The activist efforts of the parents of victims and student survivors were not constructed as a racialized response to trauma, unlike the activist efforts of Black mothers. ${ }^{1}$ Notably, even the shooter was deracialized and degendered: the shooter's race and gender were not described by media outlets as potential contributing factors to his violence. Although the shooter was reported by several media outlets to have vocalized explicitly white supremacist and misogynistic sentiments on his social media accounts, public tropes surrounding the shooter characterized him as a mentally unstable individual who had "fallen through the cracks," rather than someone driven by a white supremacist, misogynistic masculinity. For our purposes here, the point is not that he should have been framed differently, but rather that he could have been framed differently and was not. As such, the shooting did not expose racial divides but rather generalized the experience of the Parkland students to that of American kids' experiences of gun violence. The debate was not about whether the students were "really" victims and the shooter was "really" an aggressor, but about whether to protect American lives by decreasing gun violence or to maintain American ideals by promoting gun rights.

Thus far, we have compared the racialized experiences of trauma incited by the Trayvon Martin and Parkland tragedies insofar as racial dynamics shape the resources, legal and political responses, and cultural tropes available to survivors. We use this as a foundation to further tease apart how racialized trauma shapes how people in the US experience and expect everyday gun violence.

Indeed, while the likelihood of gun violence victimization is shaped by race, class, and gender, parents across these social divides nevertheless take proactive approaches to anticipate trauma. We isolate two forms of anticipatory trauma that received heightened public view in the aftermath of the Trayvon Martin and Parkland tragedies, what we call "the Race Talk" and "the Gun Violence Talk".

\section{Anticipatory trauma}

In recent years, the American market has seen an influx of products meant to protect schoolchildren in the event of an active shooter scenario. There have been multiple iterations of the bulletproof backpack, and a 14-year-old student made national news after inventing a collapsible bulletproof wall that could be expanded to cover a classroom door (Smith and Tang, 2018). Schools participate in frequent lockdown drills, training students to silently duck under desks and climb into closets should an active shooter enter the building. Protective measures and security consumption signal the constant fear and anxiety that has accompanied the potential threat of school-based gun violence since the school shooting at Columbine in the late 1990s. The 20th century had already brought an increase in social anxieties surrounding children and childhood innocence; as risk scholars Jackson and Scott (1999, p. 86) note, "childhood is increasingly being constructed as a precious realm under siege by those who would rob children of their childhoods, and as being subverted from within by children who refuse to remain childlike." Into the $21^{\text {st }}$ century, the threat of active shootings in schools compounded these anxieties, fueling new industries, new political discourses, and new policies and practices.

At the heart of these developments is the anticipation of trauma. We use "anticipatory trauma" to refer to practices and discourses grounded in fear of disasters, large-scale threats, and sudden violence by those exposed via media but not yet directly affected (Houston, 2009; Pfefferbaum et al., 2014). Psychologists have used terms such as "anticipatory stress reaction" and "pretraumatic stress disorder" to signal the similarity in psychological states-"negative affect, depression, anxiety, stress, neuroticism, and repetitive negative thinking" (Hopwood et al., 2019, p. 1427) -in individuals impacted by the fear of future events as compared to those impacted by their aftermath. Our development of "anticipatory trauma" builds on these insights but signals a sociological shift; rather than the psychological states associated with this anticipation, we are interested in socially patterned practices and discourses to manage it.

Active shootings reflect one powerful site to investigate gun violence-based anticipatory trauma, but they are not the only venue. For decades, Black parents have dealt with the anticipation of violence against their children, particularly their sons, through gun violence carried out during interactions with law enforcement and other violent actors who perceive Black children as threats. To protect their children and prepare them for the possibility that someone may attempt to harm them, Black parents engage their children in discussions about self-policing and behavior modification, otherwise known as "the Talk." Active shootings have inspired a new form of the Talk, one that white parents now participate in when attempting to protect their school-age children. In this paper, we theoretically unravel these parental talks as illustrations of racialized anticipatory trauma. With justifiable homicide deaths disproportionately borne by communities whose pain is disproportionately devalued (see, for example, the racial empathy gap; Trawalter, Hoffman and Waytz, 2012), people-particularly parents-cope with the anticipatory trauma of their children being racially stereotyped as threats by engaging in the Talk: an informal set of guidelines on how to dress and comport oneself; how to interact with peers, adults, and especially the police in public; and how to modify one's behavior depending on the time of day and the neighborhood. The Talk functions as an attempt to mitigate the powerlessness parents 
may feel when reminded that, although their children face constant potential danger due to racial stereotyping, they cannot be constantly present to physically protect their kids from harm (Whitaker and Snell, 2016). Mothers in one study (Dow, 2016) mourned the choice: to engage in the Talk in the hopes of keeping their kids alive was also to take away their childhood innocencea reality of which white Americans were largely ignorant. Furthermore, the Talk, as Gonzalez (2019) details in her study, reflects an intersectional understanding of danger, conceptualizing boys of color as the primary targets of police violence, while de-emphasizing not just girls and women of color as the victims of violence but also the kinds of violence, especially sexual and intimate partner violence, disproportionately likely to affect them.

With new discussions arising around active shootings, white Americans are beginning to face the same dilemmas; parents must make a choice between maintaining childhood innocence and providing their children with potentially life-saving information. While the Talk has typically been understood in terms of racial disadvantage, it is also pertinent to consider it in terms of racial advantage. How is the threat of gun violence differently constructed from the perspective of advantage as opposed to disadvantage? Who has the ability to sustain childhood innocence, with what tools, and at what cost? Who has the privilege to choose how to talk to their children about gun violence-or to not talk to them at all?

What we term "the Race Talk" teaches Black children to avoid gun violence through self-policing and de-escalation measures meant to avoid being perceived as a potential threat to a would-be shooter. White children are taught through "the Gun Violence Talk" that their own behavior is not the problem and cannot curb potential threats; rather, avoiding gun violence is dependent on understanding how to physically protect oneself from an active shooter. The two talks are differentiated based both on the structural contexts in which they occur and by the differently racialized language of affect and care that accompanies each. See Table 1.

First, the Gun Violence Talk is distinct from the Race Talk with regard to the presumptions regarding children's safety. The Gun Violence talk helps to reassure children that they are primarily safe and that the authority figures around them will protect them. Precautions like lockdown drills are structured through a playtype lens that allows children to separate drills from reality and maintain their sense of safety. The Race Talk, on the other hand, centers on a sense of impending peril and constant danger; there is no space for play-type language, because playing in a racialized body can easily be interpreted as threatening by law enforcement and other authorities. Rather than emphasizing reliance on authority figures to maintain safety, the Race Talk necessarily reminds Black children that authority figures may, in fact, be sources of danger, and that Black people must rely on themselves and the policing of their own behaviors for the maintenance of

\section{Table 1 Anticipatory Trauma: The Gun Violence Talk and the Race Talk}

\begin{tabular}{ll} 
The Gun Violence Talk & The Race Talk \\
\hline Safety as norm & Danger as norm \\
Precautions as play & Precautions as peril \\
Authority as caring & Authority as threatening \\
Emotions as inherently valuable and & Bodies as inherently devalued and \\
protected & imperiled \\
Passive management of emotions & $\begin{array}{l}\text { Active management of } \\
\text { embodiment }\end{array}$ \\
Grounded in formal institution & Grounded in informal community \\
efforts & practice
\end{tabular}

their own physical safety. Second, and accordingly, the Race Talk assumes a cultural context in which non-white bodies are inherently devalued and survival is an active goal rather than a likely outcome. Lives must be vigorously defended and maintained; living beyond young adulthood cannot necessarily be assumed, and precautions-oftentimes embodied behaviorsmust be undertaken against potential dangers. The Gun Violence Talk takes the opposite approach; it is not explicitly racialized or focused on embodiment as the primary cause of violence or precaution against it. Instead, it focuses primarily on managing children's emotions in anticipation of school-based active shooter scenarios, reinforcing that the behaviors of the children are not responsible for violence done against them. Finally, the Gun Violence Talk is distinct from the Race Talk with regard to the structures of support provided to parents for orchestrating the talk itself; while the Race Talk stems from embodied knowledge and has been passed down generationally with little to no support from formal institutions, the Gun Violence Talk has emerged from institutional efforts to address active shootings, including many government and media publications focused on providing parents with resources for talking with their children.

\section{The race talk and the gun violence talk as racialized anticipatory trauma}

As parallel forms of carework, the Race Talk and the Gun Violence Talk reflect two racially distinctive social structures in which the anticipatory trauma of gun violence is addressed. The Race Talk presumes social disorganization, including depressed resources, gutted expectations about life chances, and anemic institutional support, while the Gun Violence Talk presumes social organization, including available resources, expectations about a future life trajectory, and some semblance of institutional support.

Presumptions and precaution regarding children's safety. The specific language and rhetoric used within the Gun Violence Talk and the Race Talk differ significantly. The language of the Gun Violence Talk focuses primarily on reinforcing the idea of safety and maintaining childhood innocence and emotional stability, while the language of the Race Talk enforces a sense of danger, focusing on self-policing and privileging embodied safety over innocence and emotion.

The maintenance of childhood innocence is exemplified through the differential preparedness mechanisms that inform these Talks. School lockdown and active shooter drills are frequently precursors to the Gun Violence Talk. In many schools, especially for younger children, active shooter drills are reimagined in order to make them less scary for children. Rather than telling children that they are having an active shooter drill, teachers may explain that they are hiding from a dangerous animal intruder, like a bear or a tiger that has gotten loose in the school (Christakis, 2019; Hamblin, 2019; Dvorak, 2018). Alternatively, they may tell children that it is time for a "hiding game or quiet time drill" (Coppa, 2018) or a "self-control drill" (Hamblin, 2019), encourage students to create a barricade in front of the door by stacking chairs "like a fort" (Christakis, 2019), or practice singing lockdown instructions to the tune of “Twinkle Twinkle Little Star" (Christakis, 2019). By reimagining active shooter drills through the lens of play, teachers attempt to avoid potential traumatization and maintain a level of childhood innocence in their students.

Black parents giving the Race Talk are not afforded play-type lenses through which to frame their attempts at preparing their children to face danger. One of the main points of the Race Talk is to explain to Black boys and young men that even actions that 
seem innocent may be used as an excuse by someone who wants to perpetrate violence against them. Trayvon Martin was deemed "suspicious" and subsequently killed by George Zimmerman while simply attempting to walk home at night after purchasing snacks at a nearby store; he "died with a package of Skittles in his pocket" (Owens, 2012). Twelve-year-old Tamir Rice was shot and killed by white police officer Timothy Loehmann for playing with a toy gun in a park (Ly and Hanna, 2014). There is seemingly no end to the examples that could be provided. And so a key aspect of the Race Talk is Black parents explaining how even the most innocent, playful behaviors may be viewed by white people and/ or law enforcement as threatening or criminal. The Race Talk has no room for introducing an element of play as a mechanism for the maintenance of innocence, because it must address the reality of violence and explain how innocence itself may be dangerous. As Bryan Adamson (2013) writes, "Even a man of color's most benign behavior won't save him."

These different approaches to maintaining innocence also manifest in the ways danger and safety are discussed in the Gun Violence Talk and the Race Talk. The Gun Violence Talk and accompanying drills place primary emphasis on safety and the maintenance of schools as safe spaces for children. Guides encourage parents to frame schools within the Gun Violence Talk as spaces that are primarily safe but may experience rare, random violence (Turner, 2018). They encourage parents to emphasize safety measures that are already in place in schools and are not in any way dependent on the behaviors of the children (e.g., locked school doors and the presence of authority figures; CastroVillarreal, 2018). Parents encourage children to remember that they are safe in schools and that the likelihood of having an active shooter scenario is very low.

The Race Talk cannot emphasize safety as primary and danger as secondary. Black parents must explain to their children that danger is not particularly unlikely, and that in order to maintain safety, children must "self-police" their behaviors (Adamson, 2013). The responsibility for safety, rather than being placed in the hands of authority figures near the children, is placed with the children themselves. Authority figures are not a source of comfort but a primary source of potential danger. A parent's wish to maintain a child's feeling of safety is necessarily eclipsed by the need to make children aware of the persistent potential for deadly violence.

The Gun Violence Talk and the Race Talk address violence that has occurred in distinct ways. After an active shooting in a school, much of the resulting debate focuses on the shocking and rare nature of the event and "otherizes" the concept of school shootings; "I just didn't think this could ever happen here" is repeated in many different forms by many different people. Following the Parkland Shooting, the South Florida Sun Sentinel published an article in which the author stated that "Fears that have seemed distant are now on our doorstep" (Jhon, 2018). For Parkland in particular, a low-violence, high-income city near Miami, a school shooting was considered by residents to be especially jarring and surprising. The all-American perfection maintained by this city intentionally designed to feel like an oversized park was shaken by the realization that even it was not immune to school shootings. This shock was furthered by the failure of the authority figures-specifically school resource officers-this community had trusted to intervene and maintain safety. In an effort to recuperate the vision of the community that individuals held before the school shooting, there were calls for media and politicians to neglect to name the perpetrator in their coverage and discussions of the event. This was purportedly to prevent the shooter from gaining the notoriety they may have been looking for and to encourage people to instead remember the victims, but it also served the secondary purpose of allowing communities to situate the shooter as an outsider rather than a community member, making space for the recuperation of the image of the community.

Rather than framing violence that has occurred as a problem from other communities that has suddenly and shockingly invaded one's own, the Race Talk discusses violence as a pervasive issue that could equally impact nearly any community. The Race Talk avoids the "how could it ever happen here" language used in the Gun Violence Talk, instead recognizing that even in-and perhaps especially in-neighborhoods that are considered safe or affluent, there is still significant danger for Black men (Person, 2013; Washington, 2012). Here, explicitly naming the perpetrator is a method of assigning responsibility, as well as attempting to ensure justice. In the aftermath of many school shootings, the perpetrator is either dead or has been apprehended by police, and there is little to no question of whether they will be held responsible. In cases like the shooting of Trayvon Martin (or Tamir Rice, or Mike Brown...), reminding individuals of the name of the perpetrator is one attempt to guarantee justice for the victim. The naming of the perpetrator does not replace the naming of victims, on whom social media movements like \#SayHerName and \#SayTheirNames focus, but instead declines to allow perpetrators to fade from public narratives.

Embodied survival, emotional management. In the aftermath of the killing of Trayvon Martin, news outlets popularized a longstanding practice within Black families: "the Talk," or what we critically label in this paper "the Race Talk," aimed at informing Black children-and especially Black boys-of their embodied precarity. Described as a "rite of passage for black boys in America" (Parker, 2012), the Race Talk situates parents as the instructors of an impossible lesson: explaining racism and its imminent dangers to children (Dow, 2016). Balancing exposure to the "complexities of the world" (E. Thomas, 2013) with the need to allow children to be children, parents are often described as having to explain that "some things are not going to be fair" (E. Thomas, 2013); that "politeness" won't save children from judgment (Parker, 2012); and that "far too often, the justice system and our society see our boys as disposable and dispensable" (Person, 2013). A practice engaged by parents, the Race Talk is nevertheless embedded in a distinctive social structure that shapes its contours as carework.

The Race Talk reflects the social disorganization that disproportionately characterizes racialized communities (Anderson, 2012). In such structural contexts, survival is not an assumption but an achievement, and coming of age is not growing up but surviving. As such, parents find themselves less concerned with how to cultivate their children's selves (as in middle-class and white households), instead focusing on the basics of day-to-day survival. Such survival is not simply curtailed by lacking resources but also by the authority figures (such as police) who are putatively worthy of trust and legitimacy yet aggravate and undermine children's capacity for survival. As one columnist notes, "parents of black and brown children bear the chilling burden of instructing them how to behave, places to avoid, what to wear or not wear and what to say or not say in the face of law enforcement" (Adamson, 2013). Emphasizing that Black boys must anticipate the reality of malice (whether of police officers, merchants, or the private civilian), parents are situated as experts in the embodied tactics of self-policing that Black children are encouraged to adopt. The social apparatus of care that undergirds the Race Talk is rooted in the everyday tactics that parents and other adult community members have long perfected; as one columnist notes, "I'm an avid tennis player. When I used to drive to the court, I would toss my wallet into the 
glove compartment when I got into the car. But, ever wary of DWB (Driving While Black), long ago I decided to keep my wallet on the passenger's seat. There's always a chance that I'll get pulled over by an anxious, overly aggressive or even racist officer, and if I reach for the glove compartment to get my driver's license, my fingertips may never reach their destination" (R. Thomas, 2013).

In contrast, the Gun Violence Talk tends to focus on risk management-not unlike "disaster preparedness." News coverage, for example, compares active shooting drills to "naturaldisaster and Cold War drills... exposing kids to the idea that at any point, someone they know may try to kill them" (Hamblin, 2019). However, articles often stress the drills themselves as traumatizing, expressing concern not over the life-or-death stakes at play (as in the Race Talk) but rather over children's emotional states, asking, for example, "what are the longer-term effects on the children's health and development?" Such a question seems almost a luxury in the context of the Race Talk but comprises a central aspect of Gun Violence coverage. As such, parents are encouraged, as one news article summarized, to "remind children and teens that, in spite of the headlines, schools are still the safest place for them to be" and that drills should be designed to counteract feelings of powerlessness that children have in the aftermath of a widely covered school shooting in order to "help a child feel safer but also give her a sense of agency." Indeed, some coverage even insists that "the drills themselves aren't inherently scary" (Coppa, 2018), and parents talking to children about active shootings can help quell any associated anxieties.

Accordingly, parents engaging in the Gun Violence Talk are encouraged to mine their children's emotions, help children to view their environments as safe despite news reports that suggest otherwise, and even engage in therapeutic tactics (e.g., "Encourage them to talk about how they're feeling. Be alert to signs of anxiety. Practice ways to reduce stress. Take a walk, do deep breathing exercises. Maintain routines"; Bland, 2018). Whereas the Race Talk encourages kids to modify their embodiment in order to physically survive, the Gun Violence Talk encourages kids to manage their emotions. Perhaps this is because of a final key structural difference between the contexts in which the Race Talk and the Gun Violence Talk occur: rather than first-hand or secondhand experiences-which drive the Race Talk-the Gun Violence Talk revolves around addressing events and tragedies that, while widely reported and broadly known, are nevertheless experienced vicariously, either through news reports or active shooter drills.

Optional talks, unwitting experts. In the aftermath of the Parkland Shooting, news coverage included commentary from anxious parents, but it also broadly consulted professionals and experts-psychologists, counselors, security specialists-in order to apprehend the "best practices" of discussing active shootings with children. Many media outlets have published guides to help parents better navigate discussing active shootings while centering the children's emotional wellbeing; these frequently provide recommendations for age-appropriate topics to discuss with different-aged children. Rather than merely regretting that parents have to "bear the burden" of talking to their children about gun violence, such coverage proactively provides expert advice to parents. One article, for example, consults licensed mental health counselor Linda Close to guide parents through the steps of talking to children about active shootings, encouraging parents to limit children's exposure to news, to catalog and identify their own emotions, to prioritize their children's feelings, and to remind children that they are still safe-even if news reports of gun violence of schools are rampant. Several of the guides recommend not talking to younger children about shootings at all, operating under the assumption that only older children are likely to have been exposed to news coverage (Jhon, 2018; Holohan, 2019). Some parents advise never giving children a dedicated Gun Violence Talk; instead, they argue for listening to the specific concerns of children and responding directly to those particular concerns as they arise (Bland, 2018). Other guides suggest not broaching the Gun Violence Talk until the child approaches a parent and is adequately emotionally prepared (Jhon, 2018; Turner, 2018; Castro-Villarreal, 2018). The possibility of violence is counterweighed by the prospect of stripping childhood innocence; guides for giving the Gun Violence Talk are structured with the intent of maintaining innocence as long as possible and pushing off the Gun Violence Talk indefinitely, dependent on the vague future emotional preparedness of the child. This is facilitated by the prospect of a future expiration date on the sense of impending doom; while active shooter scenarios occur outside of schools and gun violence is pervasive in arenas other than active shootings, the particular scenario of school shootings, which most of the guides address directly, is only a specter while children are actively attending school.

For Black boys facing racially motivated gun violence, there is no alternative option. There is no expiration date on the potential violence faced by Black boys and men. The Race Talk is not optional but imperative, and it will inform their behaviors for the rest of their lives. Fear of stripping a child of their innocence is not enough to outweigh the necessity of the Race Talk (E. Thomas, 2013; R. Thomas, 2013). The Race Talk is passed parentto-child through multiple generations in Black families (Gandbhir and Foster, 2015; Washington, 2012). It was described in one instance as "more essential than gas money," (Person, 2013); in another instance, an author stated that "a black parent who doesn't give 'the talk' to a teen-aged boy is guilty of negligence," (R. Thomas, 2013). Unlike white parents constructing the Gun Violence Talk, Black parents receive little to no formalized institutional support for the Race Talk. Major media outlets do not provide Black parents with step-by-step guides for discussing danger with their children or nuanced, age-appropriate versions of the Race Talk. Black parents rely on first-hand and secondhand experiences to shape their narrative.

These structural elements combine with rhetorical elements to make the Talks a uniquely racialized form of carework that is coconstituted with anticipatory trauma. The anticipatory trauma experienced by parents leads to the decision to either pass anticipatory trauma on to children as a way of making them alert to danger and keeping them safe, or to attempt to prevent passing anticipatory trauma on to children in order to shield them from emotional discomfort and loss of innocence. Who actually is able to choose between these options is divided along racial lines; while white parents have the privilege of choosing to hold anticipatory trauma within themselves and withhold the Gun Violence Talk from their children, Black parents view the Race Talk as an urgent necessity and therefore must pass on their anticipatory trauma to make their children actively aware of how their bodies may be a site for danger.

\section{Conclusion}

The gun debate is about guns, but it is also about so much more. Our lived experiences of gun violence are embedded in social practices and structures of inequality that fundamentally inflect how we understand guns, how they impact us, and how we imagine social change. At over 300 million circulating in the hands and households of Americans, guns comprise a core thread of US life, with gun owners and carriers turning to guns for protection and empowerment amid racial fears, feelings of 
socioeconomic precarity, and anxieties about failing social institutions (for more on the US gun context, see Carlson, 2015; Filindra and Kaplan, 2016; Mencken and Froese 2017; Stroud, 2016). At the same time, tens of thousands of people in the US die every year by guns, impacting individuals not just in the aftermath of violence but also-and perhaps more pervasively-in its anticipation. This paper has focused on unraveling one piece of the social phenomenon of guns in the US-namely, how race shapes trauma related to gun violence. We focused on two theoretically illuminating landmark cases of gun violence-the 2012 killing of Trayvon Martin and the 2018 Parkland Shooting-to develop some theoretical claims regarding gun-related trauma as a structural and discursive phenomenon that impacts immediate victims and survivors and also broader communities that see these heinous acts as intimating their own vulnerabilities to gun violence. In doing so, this paper examines trauma as a sociological phenomenon and argues that the conversations that parents of diverse backgrounds undertake in anticipation of gun violence provide insight into anticipatory trauma as a racially inflected experience.

Reading mainstream news accounts of parents' responses to gun violence, we suggest that there is no singular "Talk"; instead, there are many Talks, differentiated along racial lines. Black parents must prepare their children for interactions that may become deadly due to their race, while white parents need not engage their children in a discussion of how their physical bodies may lead to them being disproportionately targeted for death. Black parents feel that they must give their children "the Talk" because interactions with law enforcement and other potentially violent actors are essentially inevitable; the only real choice made available to them is at what age to give "the Talk," rather than the option of opting out of "the Talk" in favor of maintaining childhood innocence. Only white parents are able to consider not giving "the Talk" as a personal parenting choice. They do not have to worry significantly about their children being racially stereotyped by law enforcement or other potentially violent actors; unlike Black children's interactions with law enforcement, they can reason that school shootings, which they can imagine as the only bodily threats to their children, are not inevitable or even particularly likely.

As gun debates heat up, it is easy to see the dramatic difference between gun control and gun rights advocates: though both motivated by the problem of gun violence, they come up with wildly divergent conclusions regarding the significance of guns themselves. For the gun control side, guns are irrevocably the problem; for the gun rights side, guns are the preferred solution. This paper is interested less in the vociferous terms of the gun debate, and more in the everyday practices that parents undertake amid a gun debate stalemate. These everyday practices, however, signal policy implications. They demonstrate that gun violence as a social phenomenon in hearts and minds far exceeds gunshot wounds exacted on bodies. While we tend to debate the intersection of mental health and guns as a law enforcement problem (i.e., how can we keep guns out of the hands of people experiencing mental health crises?), this analysis suggests the need for a broader, trauma-informed conversation that highlights the effects of gun violence on our mental health, emotional well-being, and intimate relationships-even those relationships between parent and child.

At the same time, our analysis suggests that these effects are not monolithic but shaped by the racial contexts in which gun violence becomes, if not inevitable, at least imaginable. In the US, race shapes who is most impacted by gun violence, how they are impacted, as well as the social narratives that make sense of gun violence, from the specter of the hyperaggressive black urban thug to the stylized trope of the troubled white school shooter (see, e.g.,
Carlson, 2019). As this analysis has shown, our imaginations are perhaps limited by our social positions, with implications for how we can imagine policy solutions: even in the most intimate relations between parent and child, certain acts-such as active shootings-are treated as quintessential cases of gun violence, whereas other acts-such as justifiable homicides-are addressed as issues of race, of which gun violence is one expression. As sociologists, we are trained to ask how race and other lines of inequality shape arenas in which they appear to be putatively absent. But to point out that "the Gun Violence Talk" is just as much about race as "the Race Talk" is about gun violence is not just a sociological exercise. It is also a caution for policy-makers to question popular understandings of what "counts" as gun violence-e.g., to question why assault weapons receive so much attention when handguns are involved in the vast majority of gun violence-and to thus avoid creating policies that further divide us in our experiences of gun violence. This paper, of course, represents just small piece of this puzzle; we do not analyze how suicide, negligent shootings, and other distinctive kinds of gun violence are embedded in structures of inequality through discourses of trauma, but doing so would likely expand our understandings of not just the lived experience of gun violence in the contemporary US context but also our capacity to create better solutions for addressing gun violence.

We close by emphasizing that as the statistics demonstrate, traumatic death in the US is both a gun violence issue and a race issue; not only do people in the US experience a heightened risk of gun violence as compared to other kinds of sudden traumatic death, but these risks are structured by race, as well as class and gender, inequalities. To the extent that how we anticipate gun violence narrows how we understand it as a social problem, we may also risk narrowing our imaginations as we struggle to address it, whether through the formal channels of policy craftwork or the informal channels of parental carework.

\section{Data availability}

See references for analyzed data in the form of news coverage.

Received: 26 June 2019; Accepted: 4 September 2019; Published online: 01 October 2019

\section{Notes}

1 The victims and parent and student activists from Parkland were generally deracialized. This was the case, of course, until it became politically convenient to racialize them. One of the survivors and student activists who gained the most attention from the media was then-eighteen-year-old Emma González. When she participated extensively in the gun violence prevention activism after the Parkland shootings, supporters of gun rights attempted to use González's heritage to discredit her activism. González, who is Cuban-American, was publicly attacked by Republican Representative Steve King for wearing a Cuban flag patch on her jacket at the March for Our Lives. Although the particular flag González wore was in no way associated with Castro's dictatorship, King accused González of not understanding the history of Cuba and "'[ignoring] the fact that [her] ancestors fled the island when the dictatorship turned Cuba into a prison camp, removing all weapons from its citizens; hence their right to self defense"' $(\mathrm{Oh}, 2018)$. In contrast to the deracialization of Cruz, the shooter, González's ethnicity was strategically mobilized as a method of discounting her experience with trauma that resulted from violence that was motivated at least partially by white supremacy.

\section{References}

Adamson B (2013) The racial self-policing that African-American men already do. The Seattle Times. http://old.seattletimes.com/html/opinion/2021500612_bry anadamsonoped $30 \mathrm{xml} . \mathrm{html}$

Alexander JC (2012) Trauma: a social theory, 1st edn. Polity, Malden

Al'Uqdah S, Adomako F (2018) From mourning to action: African American women's grief, pain, and activism. J Loss Trauma 23(2):91-98 
Anderson E (2012) The iconic ghetto. ANNALS Am Acad Political Soc Sci 642:8-24

Armour MP (2002) Journey of family members of homicide victims: a qualitative study of their posthomicide experience. Am J Orthopsychiatry 72(3):372

Bailey A, Hannays-King C, Clarke J, Lester E, Velasco D (2013) Black mothers' cognitive process of finding meaning and building resilience after loss of a child to gun violence. Br J Soc Work 43(2):336-354

Bland K (2018) After Parkland, stop talking to kids about school shootings and listen instead. USA Today. https://www.usatoday.com/story/life/allthemoms/ healthsafety/2018/02/23/florida-school-shooting-stop-talking-start-listeningto-kids/34925223/

Carlson J (2015) Citizen-protectors: the everyday politics of guns in an age of decline. Oxford University Press, New York

Carlson J (2019) Police warriors and police guardians: race, masculinity, and the construction of gun violence. Soc Probl. https://doi.org/10.1093/socpro/spz020

Castro-Villarreal F (2018) How to talk to your children about school violence. My San Antonio. https://www.mysanantonio.com/opinion/commentary/article/ How-to-talk-to-your-children-about-school-violence-12889092.php

Chan Tack AM, Small M (2017) Making friends in violent neighborhoods: strategies among elementary school children. Sociological Sci 4:224-248. https:// doi.org/10.15195/v4.a10

Christakis E (2019) Active-shooter drills are tragically misguided. The Atlantic. https://www.theatlantic.com/magazine/archive/2019/03/active-shooter-drillserikachristakis/580426/

Coppa C (2018) How do we talk to kids about active-shooter drills at school? Today. https://www.today.com/parents/are-kids-anxious-afraid-becauseschool-shooter-drills-t138436

Cullen D (2019) Parkland: birth of a movement, 1st edn. Harper, New York

Dow DM (2016) The deadly challenges of raising African American boys. Gend Soc 30(2):161-188. https://doi.org/10.1177/0891243216629928

Dvorak P (2018) Millions of kids fear being killed at school. It's time for adults to say: enough. The Washington Post. https://www.washingtonpost.com/local/ millions-of-kids-fear-being-killed-at-school-its-time-for-adults-to-sayenough/2018/12/27/faa0cf62-0a06-11e9-88e3-989a3e456820_story.html? utm_term $=.26045$ ea51892

Eyerman R (2013) Social theory and trauma. Acta sociologica 56(1):41-53

Eyerman R (2015) Is this America?: Katrina as cultural trauma. University of Texas Press, Austin

Eyerman R (2019) Memory, trauma, and identity. Springer, Cham

Erikson K (1976) Everything in its path. Simon and Schuster, New York

Filindra A, Kaplan NJ (2016) Racial resentment and whites' gun policy preferences in contemporary America. Political Behav 38(2):255-275

Fox JA, Levin J (1998) Multiple homicide: patterns of serial and mass murder. Crime Justice 23:407-455. https://doi.org/10.1086/449274

Gandbhir G, Foster B (2015) A conversation with my Black son. New York Times. https://www.nytimes.com/2015/03/17/opinion/a-conversation-with-myblack-son.html

Gonzalez S (2019) Making it home: an intersectional analysis of the police talk. Gend Soc 33(3):363-386

Hamblin J (2019) What are the psychological effects of 'active-shooter drills'? The Atlantic. https://www.theatlantic.com/health/archive/2018/02/effectsof-active-shooter $/ 554150 /$

Herman JL (2015) Trauma and recovery: the aftermath of violence-from domestic abuse to political terror. Basic Books, New York

Hertz P-S, Chery (2005) Homicide survivors: research and practice implications. Am J Preventive Med 29(5):288-295. https://doi.org/10.1016/j.amepre. 2005.08.027

Holohan M (2019) How to talk to children about shootings: an age-by-age guide. Today. https://www.today.com/parents/how-talk-children-about-shootingsage-age-guide-t59626

Hopwood TL, Schutte NS, Loi NM (2019) Anticipatory traumatic reaction: outcomes arising from secondary exposure to disasters and large-scale threats. Assessment 26(8):1427-1443

Houston JB (2009) Media coverage of terrorism: a metaanalytic assessment of media use and posttraumatic stress. Journalism Mass Commun Q 86:844-861. https://doi.org/10.1177/107769900908600408

Jackson S, Scott S (1999) Risk anxiety and the social construction of children. In: Lupton D (ed) Risk and sociocultural theory. Cambridge University Press, Cambridge, p 86-107

Jhon J (2018) How to talk to your children about school shootings, South Florida Sun Sentinel. https://www.sun-sentinel.com/local/broward/parkland/ florida-school-shooting/fl-school-shooting-talk-to-kids-20180214-story. html

Ly L, Hanna J (2014) Tamir rice shooting is ruled a homicide. CNN. https://www. cnn.com/2014/12/12/justice/cleveland-tamir-rice/index.html

Madfis E (2014) Triple entitlement and homicidal anger: an exploration of the intersectional identities of American mass murderers. Men Masculinities 17(1):67-86. https://doi.org/10.1177/1097184x14523432
McGuffey CS (2005) Engendering trauma: race, class, and gender reaffirmation after child sexual abuse. Gend Soc 19(5):621-643

Melendez MS, Lichtenstein B, Dolliver MJ (2016) Mothers of mass murderers: exploring public blame for the mothers of school shooters through an application of courtesy stigma to the Columbine and Newtown tragedies. Deviant Behav 37(5):525-536. https://doi.org/10.1080/01639625.2015 1060754

Mencken FC, Froese P (2017) Gun culture in action. Social Problems 66(1):3-27

Morris S (2018) Mass shootings in the US: There have been 1,624 in 1,870 days. The Guardian. https://www.theguardian.com/us-news/ng-interactive/2017/ oct/02/america-mass-shootings-gun-violence

Morrison DR, Casper MJ (2012) Intersections of disability studies and critical trauma studies: a provocation. Disability Stud Quart 32(2). https://doi.org/ 10.18061/dsq.v32i2.3189

Oh I (2018) Rep. Steve King mocks Emma Gonzalez for wearing a Cuban flag patch. Mother Jones. https://www.motherjones.com/politics/2018/03/repsteve-king-mocks-emma-gonzalez-for-wearing-a-cuban-flag-patch/

Onwuachi-Willig A (2016) The trauma of the routine: lessons on cultural trauma from the Emmett Till verdict. Sociol Theory 34(4):335-357. https://doi.org/ $10.1177 / 0735275116679864$

Owens D (2012) After Trayvon, a black father has 'The Talk' with his son. Baltimore Sun. https://www.baltimoresun.com/news/opinion/oped/bs-ed-father20120326-story.html

Parker LO (2012) Trayvon Martin's death: a community mourns. The Washington Post. https://www.washingtonpost.com/blogs/therootdc/post/trayvon-martinsdeath-a-community-mourns/2012/03/21/gIQAvxMyRS_blog.html? utm_term $=.2$ adbe8f866e7

Payne BK (2006) Weapon bias: split-second decisions and unintended stereotyping. Curr Directions Psychological Sci 15(6):287-291. https://doi.org/ 10.1111/j.1467-8721.2006.00454.x

Person, D. (2013) Black parents fret over what to tell sons: column. USA Today https://www.usatoday.com/story/opinion/2013/07/14/david-person-onblack-parents-and-sons/2516381/

Pew Research Center (2013) Big racial divide over Zimmerman verdict, Pew Research Center. https://www.people-press.org/2013/07/22/big-racial-divideover-zimmerman-verdict/

Pfefferbaum B, Newman E, Nelson SD, Nitiéma P, Pfefferbaum RL, Rahman A (2014) Disaster media coverage and psychological outcomes: descriptive findings in the extant research. Curr Psychiatry Rep 16:464. https://doi.org/ 10.1007/s11920-014-0464-x

Price MJ (2017) What would mama do? Save our sons and daughters (SOSAD) and anti-violence organizing among Black mothers of murdered children in Detroit

Roman JK (2013) Race, justifiable homicide, and stand your ground laws: analysis of FBI supplementary homicide report data (Publication No. 243328). http:// www.ncjrs.gov/App/publications/abstract.aspx? $\mathrm{ID}=265405$

Schmidt IB (2014) Perpetual trauma and its organizations: mothers against drunk driving and drunk driving revisited. Mem Stud 7(2):239-253. https://doi.org/ $10.1177 / 1750698012470836$

Sharkey P (2010) The acute effect of local homicides on children's cognitive performance. Proc Natl Acad Sci 107(26):11733-11738

Sharkey PT, Tirado-Strayer N, Papachristos AV, Raver CC (2012) The effect of local violence on children's attention and impulse control. Am J Public Health 102(12):2287-2293. https://doi.org/10.2105/ajph.2012.300789

Smelser N (2004) Psychological trauma and cultural trauma. In: Alexander J, Eyerman R, Giesen B, Smelser N, Sztompka P (eds) Cultural trauma and collective identity. University of California Press, Berkeley, p 31-59

Smith O, Tang E (2018) This 14-year-old inventor designed a bulletproof wall to protect students during school shootings. ABC News. https://abcnews.go. com/GMA/News/14-year-inventor-designed-bulletproof-wall-protectstude nts/story?id $=57115216$

Stroud A (2016) Good guys with guns: the appeal and consequences of concealed carry. UNC Press, Chapel Hill

Tate J, Jenkins J, Rich S, Muyskens J, Elliott K, Mellnik T, Williams A (2016) How the Washington Post is examining police shootings in the United States. The Washington Post. https://www.washingtonpost.com/national/ how-the-washington-post-is-examining-police-shootings-in-the-unitedstates/2016/07/07/d9c52238-43ad-11e6-8856-f26de2537a9d_story.html? noredirect $=$ on

Thomas E (2013) Forest Whitaker falsely accused of shoplifting: How do I explain racism to my son? The Washington Post. https://www.washingtonpost.com/ blogs/therootdc/post/forest-whitaker-falsely-accused-of-shoplifting-how-doi-explain-racism-to-my-son/2013/02/21/164886d2-7c65-11e2-a044676856536b40_blog.html?noredirect $=$ on

Thomas R (2013) 'The Talk' has a double meaning for Black people, Huffington Post. https://www.huffingtonpost.com/ron-thomas/the-talk-has-a-doublemea_b_3645809.html 
Trawalter S, Hoffman KM, Waytz A (2012) Racial bias in perceptions of others' pain, PLoS ONE 7(11). https://doi.org/10.1371/journal.pone.0048546

Turner C (2018) How to talk with kids about terrible things, NPR. https://www. npr.org/sections/ed/2018/02/18/586447438/how-to-talk-with-kids-aboutterrible-things

Washington J (2012) Trayvon Martin, my son and the Black Male Code. NBC News. http://www.nbcnews.com/id/46843826/ns/us_news-life/t/trayvon-martin-myson-black-male-code/\#.XJme0y2ZPUo

Whitaker TR, Snell CL (2016) Parenting while powerless: consequences of "the talk”. J Hum Behav Soc Environ 26(3-4):303-309. https://doi.org/10.1080/ 10911359.2015.1127736

\section{Acknowledgements}

This study was supported by a University of Arizona Faculty Seed Grant. The authors would like to thank Letta Page for her crucial assistance in wordsmithing.

\section{Competing interests}

The authors declare no competing interests.

\section{Additional information}

Correspondence and requests for materials should be addressed to J.C.
Reprints and permission information is available online at http://www.nature.com/ reprints

Publisher's note Springer Nature remains neutral with regard to jurisdictional claims in published maps and institutional affiliations.

\section{(c) (i)}

Open Access This article is licensed under a Creative Commons Attribution 4.0 International License, which permits use, sharing, adaptation, distribution and reproduction in any medium or format, as long as you give appropriate credit to the original author(s) and the source, provide a link to the Creative Commons license, and indicate if changes were made. The images or other third party material in this article are included in the article's Creative Commons license, unless indicated otherwise in a credit line to the material. If material is not included in the article's Creative Commons license and your intended use is not permitted by statutory regulation or exceeds the permitted use, you will need to obtain permission directly from the copyright holder. To view a copy of this license, visit http://creativecommons.org/ licenses/by/4.0/.

(C) The Author(s) 2019 